\title{
MIXED QUESTIONS OF LAW AND FACT.
}

The common law does not profess to lay down a minute code of definite standards by which the conduct of mankind is to be judged in every combination of circumstances which nay possibly arise. It recognizes the futility of any attempt to fix such standards, and often contents itself with announcing broad general principles which give the material and general directions for the construction of the standard to be applied in each specitic case as it nay arise. While such broad general principles are not peculiar to the law of Torts, they appear most frequently in it, and particularly in that part of it which deals with wrongs caused by the breach of a duty to refrain from conduct creating an undue probability of harm to the legally protected interests of others, popularly called "negligence."

In every action of "negligence" two questions arise: ( 1 ) should the defendant, as a reasonable man. have recognized that the plaintiff's interests are within range of the effects of his conduct, and (2) if so, should he, as a reasonable man, have realized that his conduct contained a probability of harm to some legally protected interest of the plaintiff, out of proportion to its social value and utility? In neither does the law generally attempt to state the precise circumstances which require the defendant to realize the plaintiff's proximity to the scene of his conduct, nor the precise circunstances which should apprise the defendant that his conduct contains a probability of harm in excess of its social value.

In many actions of "negligence" the further question arises: has the plaintiff contributed to his injury by conduct of his own, which, as a reasonable man, he should have recognized as containing an undue probability of harm to the interests 1 hich have suffered injury from the defendant's negligent. wrongdoing? 
All of these questions are generally spoken of as "mixed questions of law and fact." . This phrase is unfortunate, unless the proportions of the mixture can be clearly stated and its component elements accurately defned. While such questions are, under our system of litigation, to be determined by a jury, acting under the direction of a court, bound to follow the broad general principles of law announced by it and subject to its supervisory control, this is not peculiar to them. Every question which is left to the jury is to be determined in the same way. Yet questions, such as that of the existence of a contract or of the guilt of a particular person accused of murder, are not spoken of as "nixed questions of law and fact." It is not, therefore, the fact that the court and jury have each their own function to perform in solving such questions that makes the profession assume them to be "mixed questions of fact and law." It is the peculiar nature of the function which the jury must exercise in determining such -questions-as well as all other questions for the solution of which the law has declared no definite pre-existing rule-which has led to their being so regarded.

In order that the true nature of this peculiar function may be ascertained, it is necessary to consider what is "fact" and what is "law."

The primary and popular meaning of the word "fact" is something which has happened or existed,-including not only the physical facts of the case but also more abstract matters, such as the state of mind of those individuals, whose state of mind may be of legal importance.

"Law" primarily means a body" of principles and rules which are capable of being predicated in advance and which are so predicated, awaiting proof of the facts necessary for their application. While the court has a supervisory power over the jury's findings of fact, in the primary and popular meaning of

\footnotetext{
"See as to this and as to much of the residue of this article, "The Common Law," O. W. Holmes, Jr. (I881), p. I22 et seq.
} 
that term, yet it exercises that power sparingly. The jury has no power to declare the law, using that term in the sense above stated.

But since it is impossible to anticipate the innumerable combinations of circumstances which may arise, it is impossible for the law to formulate in advance definite standards by which the propricty of conduct under every conceivable set of circumstances may be judged. It can at best announce broad general principles, which give the materials and general directions for the construction of the standard to be applied in each specific case.

The problem of determining whether a particular act should have been recognized by the so-called reasonable man as threatening an undue probability of harm to others, requires for its solution not only the ascertainment of the facts of the case, that is, what the plaintiff and defendant did, the circumstances under which they acted and the state of mind which actuated their conduct, but also that someone, either court or jury, shall determine whether a "reasonable man" would have recognized that such conduct would create an undue probability of harm or that a "reasonable man" in the defendant's place would have realized that his conduct would unduly imperil the plaintiff's interests.

Were the "reasonable man" identical with the average man and were the question what the average conduct of mankind under similar circumstances is, the question would be purely one of fact-of what is or exists-though involving an enormously extended inquiry as to the conduct of all other men or a great number of other men under similar circumstances. But the "reasonable man" is not the average man. He is an ideal creature, expressing public opinion declared by its accredited spokesman, whether court or jury, as to what ought to be done under the circumstances by a man, who is not so engrossed in his own affairs as to disregard the effect of his conduct upon the interests of others. He may be called a personification of the court or jury's social judgment. The factor controlling the judgment of the defendant's conduct is not what is, but what ought to be. 
No matter whether the question is determined by court or jury, it is the opinion of the court or jury as to what ought to be done under the circumstances of that particular case which is controlling and which is expressed in its decision. It is the sound judgment, the sense of proportion between the utility of the act and the injury threatened, the valuation of the respective interests concerned and the actual experience of the court or jury, which is exercised and utilized.

Under our system of conducting litigation the function of reducing these broad general principles to definite standards is in theory exercised by the jury under the control and supervision of the court. In fact, it is exercised by both court and jury, the court doing so under the guise of preventing the jury from falling into manifest error.

It is clear that this function is not that of declaring the law ${ }^{2}$ in the sense in which that term has been defined, as a pre-existing rule automatically applicable to certain facts when proved to exist, and it is equally clear that it is not a finding of fact in the primary sense of that term. ${ }^{3}$ It is more nearly. akin to a declaration of law than to a finding of fact, since it does create obligatory standards, which, if created by the jury, are, it is true, binding in only the particular case then before it, but which none the less are the standards by which the conduct of the parties to that litigation is to be judged to determine their respective legal rights and liabilities. The fact that it is not called a pure question of fact shows that the profession has felt the kinship which the function exercised by the jury has to that which courts exercise in declaring law in its primary sense, but the legal profession has so long accepted it as axiomatic that the jury has no power except to find facts, that any question left to a jury is taken to be at least in part a question of fact.

\footnotetext{
"See, however, Mr. Justice Holmes, "Law in Science and Science in Law," 12 Hakv. L Rev. 43 ( $1 \& 98)$, at p. 457.

"But see James Bradley Thayer, "Law and Fact' in Jury Trials," 4 HARV. L. REV: I47 (1890), at p. I69.
} 
But it is time to recognize that this supposed axiom is not accurate. Until comparatively recently it was thought to be equally axiomatic that courts had no power to find facts, but now it is universally recognized that courts not only may but often must make findings of fact in the primary and proper sense of that term. There seems, therefore, no reason why it should not be recognized that the function which the jury exercises in defining standards of conduct is that of declaring the standard by which the consequence of some particular act or omission is to be determined. Whatever else this is, it is not that of finding the existence of any fact or facts, and is not a law-declaratory function as the term is ordinarily used. It is something between the two, necessary to the proper administration of the pre-existing broadly stated law by making it capable of application to the facts of specific litigated cases, and may be properly termed "administrative."

To so term it should cause no shock to the legal mind, which has become habituated to the term "administrative" as applied to the very similar function entrusted by many legislative acts to Boards and Commissions. Many modern acts show that legislatures, like the common law, realize the impossibility of prescribing a definite rule for every conceivable situation. These acts are, therefore, couched in much such broad general tcrms as those in which the law announces its general principles. Thus, they avoid rigidity and the danger that standards and rules which, at the time they were enacted seem useful or necessary, may become impracticable and ridiculous under changed conditions. These acts, therefore, create administrative boards and commissions whose duty, like that of a jury in a negligence case, is to gain information and experience and to create standards applicable to specific situations in accordance with the general principles of the act. These standards, it is true, differ from those created by a jury in that they have not the purely ephemeral character which the finding of a jury has, but are valid until changed by the Board or Commission.

But, on the other hand, they have not the absolute finality which a legislatively enacted standard would have, but are 
flexible, open to reconsideration and change, if changed conditions prove that they no longer adequately express the general principle of the act.

\section{II}

The reasons why the function of fixing definite standards is in theory to be exercised by the jury and is in practice exercised by both court and jury, rather than by the court alone are in part historical, in part, express the public's desire to have its conduct judged by the layman ("the man in the street") rather than by the more sophisticated and expert judgment of the trained lawyer, whose judicial experience may have given him a biased point of view.

Entrusting it to the jury has the advantage of preventing the same sort of rigidity which legislators avoid by the creation of Administrative Boards, and which would result from a judicial declaration of particular standards.

The traditional view that a judicial ruling on any subject announces a principle of law fixed, permanent and immutable, affixes these qualities to a standard of conduct judicially fixed as required by the circumstances of a particular case, and not only makes that standard a rule to which others must conform in the future, but prevents its re-examination no matter how material conditions and popular opinion have changed.

The decision of a jury determines the standard for the one case, and for that case only. It operates only e.x post facto. It does not create, as would a decision of the court or a ruling by an administrative board, until changed, a standard to which others must conform in the future. It creates merely standards to which the defendant must have conformed to have escaped liability, and to which the plaintiff must have conformed to prevent him from being guilty of contributory negligence and so barred from recovery, though neither defendant nor plaintiff could have known of it in advance and must, therefore, have taken the risk that his moral and social standard shall have conformed to that of the jury. Such a standard, once used to determine the wrongfulness of the act or omission of the de- 
fendant in a particular case, has fulfilled its purpose. It has no force, binding or persuasive, in determining whether identical conduct under identical circumstances is right or wrong. Thus, room is left for a change of standard when a change in the physical conditions of life, or a change in the public valuation of the respective interests concerned, require it.

It may be that this leares standards of conduct too uncertain and indefinite. The purely ephemeral character of the jury's findings leads to results which laymen at least regard as unjust. To the lay mind, justice essentially requires that the same conduct under the same circumstances shall entail the same liability. Yet it constantly happens that in identical situations, one jury will fix a standard which permits a recovery and another will set a standard which denies it.

The difficulty lies in the fact that the common law has no machinery, like the legislatively created administrative board, which can make rulings reducing general rules to that particularity necessary for their application to individual cases, which have not only a validity until changed but a notoriety which may serve as a guide to those who desire that their conduct may not entail liability, but which the administrative bodies not only may, but must, re-examine from time to time to determine whether they still are valid in view of changed conditions and changed public opinion as to the value of the respective.interests concerned.

\section{III}

While the function of fixing definite standards is in theory assumed to be exercised by the jury under the control of the court, the court's control is far more often exercised in such matters than in keeping them from error in their findings of true fact.

There are three functions of the jury over all of which the court has control. The first is to determine the credibility of witnesses; the second is to determine the probative value of evidence produced before it; the third is the fixing of definite standards of conduct. Over the first the court exercises little 
or no control. There are now few, if any, general rules to determine which of two witnesses, whose testimony is diametrically opposed, shall be believed. Courts rarely, if ever, set aside a verdict on the ground that they are convinced that the jury attached undue weight to the testimony of a witness whose credibility it distrusted, though here the judlicial experience of a court gives it an eminent superiority of power to detect palpable perjury. They exercise a far greater control over the probative value which a jury may attach to the evidence presented.

But it is only when the jury's determination of standards of conduct is before them that they show any tendency to usurp the function of the jury, assuming that it is the exclusive function of the jury to fix such standards. The reason for this is obvious. The question as to whether a defendant has been guilty of conduct, which creates an undue probability of harm to others, requires those who judge his conduct to weigh the utility of the act against the probability of harm which it contains; not the utility of the act to the actor alone, but the utility of the act to society, the interest that society may have in permitting such conduct, notwithstanding the risk to others which it entails, because such conduct is on the whole of social value. But the general utility of such conduct is not likely to receive much consideration from a jury who sees before them a plaintiff whose vital interests have been harmed by a particular instance of it. A court might emphasize to the jury ad nauscam the social value of the act, but the jury would only see one man injured by another. And only the most confirmed optimist would dare to hope that they would judge the defendant's conduct by what that ideal creature, the "reasonable man," would do. After all the most that can be expected of a jury is that they shall judge the defendant's conduct by what the jurymen would themselves do in a similar situation. But even this they rarely do. The concept universal among all primitive men, that an injury should be paid for by him who causes it, irrespective of the moral or social quality of his conduct, while it has disappeared from legal thought, still dominates the opinion of the sort of men who form the average jury. There is, besides, the 
perhaps natural prejudice in favor of a poor man injured by a rich man, and particularly by a corporation which is always assumed to have unlimited resources. The tendency to be charitable with other people's money is almost irresistible, and when one considers that the bulk of acciclents are cansed by the business activity of corporations and the amusement activity of those who, to the jury at least, appear rich, it is not surprising that courts should feel that they are bound to protect defendants from what appears to them to be an unduly stringent standard of conduct which the jury, if the matter were left to them, would fix as a justification or excuse for a finding in favor of the plaintiff against a defendant whose conduct the courts would not regard as socially reprehensible, by withdrawing cases from the jury where they beliere that the defendant's conduct was not unduly dangerons, and by setting aside verdicts based on the jury's insistence on an overly stringent standard of conduct.

It is quite clear that due consideration can only be given to the social utility of an act which is based upon any broad general economic theory, by the court's taking the decision into its own hands. And it is immaterial whether it does so by definitely asserting the riglit to fix the standard, or by saying that the jury would be acting unreasonably if they fixed a standard which regarded as wrongful, conduct which the court believes to be justified by economic necessity. On the whole, therefore, it may well be that the tendency of courts to assume the function of fixing standards, wherever they feel that the jury will not give proper consideration to the social utility of the defendant's conduct, is necessary for the proper administration of the general principles by which a defendant's guilt or innocence should be determined.

But the practice has two great dangers. The first is that of the undue rigidity which results from the unfortunate feeling, that any decision of a court creates a rule of law which, as law, is absolutely and eternally valid. Such rigidity is especially pernicious where the decision states a standard of conduct cletermined by a comparison of the value of the interest im- 
periled and the extent of the probability of harm thereto with the social value of the conduct which threatens and causes the harm. Not only may there be changes in the physical conditions and surroundings of life by new inventions, new modes and habits of living, but there may be, and often is, a complete revaluation of the respective interests concerned. To regard a standard of conduct as fixed and inmutable because judicially announced, is to create a standard which, however just or even necessary at the time, may become a scandal and a hissing in the future.

It is true that a persistent change in public opinion as to the relative value of the interests compared, tends to find expression in judicial decision. Thus, the early decisions, which held that the landowner's interest in doing as he pleased upon his own land, was of greater value than the life and limbs of even a morally innocent intruder, have yielded to a change in public opinion which places a higher value on life and limb than upon the traditional dominional prerogative of a landowner. Yet the processes by which this change of value has forced the creation of a new standard by which the conduct of landowners is judged, has been one of continual fiction and false analogies. ${ }^{4}$ It is only recently that a few courts have had the temerity to base such decisions upon the relative values of the interests concerned. 5 And even within the last year one of the ablest and most enlightened of American judges denied recovery in a rase of an infant trespasser, because he did not come within the exact terms of a fiction, whose only purpose was to protect just such persons as infant trespassers, while appearing to adhere to archaic precedents which denied. them protection."

The second clanger is that, in its endeavor to protect defendants from the prejudice of juries, the court must by its

-F. H. Bohlen, "Owner's Duty to Those Entering His Premises of Their Own Right," 69 U. of PA. I. REv. I $12,237,340$ (1921), especially 237 to 252 , and $34,-$ to 350 : and Professor Manley O. Hudson's able and exhaustive article on "The Turntable Cases in the Federal Courts", 36 HARv. L. Rev. 826 (Ig23).

"See "The Turntable Cases in the Federal Courts," note 4, supra.

- Holmes, $J_{\text {, }}$ in Britt v. United Zine \& Chemical Co., 258 U. S. 268 (1922). 
decisions fix standards of conduct so definite and precise as to give to unscrupulous practitioners extraordinary opportunities for the successful coaching of their witnesses. This is particularly true of the very minute and rigid codes of standards, judicially established in some jurisdictions, to which plaintiffs must conform to clear themselves of contributory negligence. Often these standards tend to degenerate into an etiquette or ritual, having little or no relation to what any normal person would regard as being obligatory under the various circumstances which they cover. In such cases unscrupulous practitioners know exactly what they must prove to escape a non-suit or a directed verdict for the defendant.

It is no uncommon experience to hear uneducated witnesses describe the conduct of the plaintiff in terms which are almost a literal repetition of the latest opinion by some justice of the supreme court of the particular state. This may be a mere coincidence. It is not impossible that even an ignorant foreigner recently come to this country may have a mind whose operations are so like those of a justice of a supreme court as to lead him to speak in substantially identical language. But it does not seem uncharitable to suspect that careful instruction by practitioners, whose interest it is to study such opinions minutely, is responsible for such testimony. Thus, courts, in their endeavor to protect the defendant, often overshoot their mark and put a weapon in the hands of those who prostitute their profession by false claims in which they have a direct and material interest. But even if this practice is not as prevalent as one is led to believe by the statements constantly made by lawyers, whose principal business is in defending accident cases, yet the very rigidity of the rules. the insistence that the plaintiff must exercise a degree of care which the ordinary man would regard as altogether unnecessary, is apt to lead the jury to believe that, if the court leaves the case to them, they are substantially directed to find a verdict for the plaintiff. It is true they need little urging, but at the same time it seems impossible to ignore the effect of arguments, made before them on motions 
for non-suits, in which the court is asked to apply to the plaintiff's conduct standards which the jury regards as unnecessarily severe, as leading them to feel that their function is only to register a verdict in favor of the plaintiff.

Is it too much to hope that courts, who must often take over this function from the jury in order to give proper weight to the social utility of conduct which undoubtedly threatens harm to the legally protected interests of others, will realize that, in so doing, they are exercising an administrative function and that such decisions are not, like their decisions construing and declaring those principles which are fundamental to our concept of law, sacrosanct from judicial re-examination and change under changing conditions?

Francis $H$. Bohlen.

Unizcrsity of Pennsylvania Law School. 